\title{
THE ASYMMETRIC VOLATILITY OF THE ISLAMIC CAPITAL MARKET DURING THE COVID-19 PANDEMIC
}

\author{
Achmad Nurdany ${ }^{1}$, Muhammad Hanif Ibrahim² ${ }^{2}$ and \\ Muhammad Fathul Romadoni ${ }^{3}$ \\ ${ }^{1}$ UIN Sunan Kalijaga Yogyakarta, Indonesia, achmad.nurdany@uin-suka.ac.id \\ ${ }^{2}$ UIN Sunan Kalijaga Yogyakarta, Indonesia, muhammadhanifibrahim47@gmail.com \\ ${ }^{3}$ UIN Sunan Kalijaga Yogyakarta, Indonesia, muhammad.fr18@gmail.com
}

\begin{abstract}
This study attempts to identify the existence of asymmetric volatility in the Islamic capital market in Indonesia during the Covid-19 pandemic. The paper employs the symmetric analysis of the GARCH $(1,1)$ model and the asymmetric analysis of the TGARCH $(1,1)$ model in order to identify Islamic capital market behaviour during the first 200 days after the first Covid-19 cases were confirmed. We used the daily closing prices of the Indonesia Sharia Stock Index (ISSI). The symmetric analysis of the GARCH $(1,1)$ model revealed that the current value of return on the ISSI does not have a significant impact on its future value. On the other hand, the TGARCH $(1,1)$ model showed that the asymmetric parameter coefficient was positive and statistically significant. Good news and bad news does not have the same level of impact on the volatility of returns on the ISSI. Furthermore, coefficients $\alpha_{i}$ and $\gamma_{i}$ in the variance equation indicate that good news has a higher volatility impact than bad news. The results indicate that investors should not to worry about the bad news effect of the Covid-19 pandemic, while the government should continue the mitigation of the spread of the coronavirus along with its economic recovery policy.
\end{abstract}

Keywords: Asymmetric model, GARCH, Islamic capital market, Covid-19 pandemic. JEL classification: C580; G1; I150.

\author{
Article history: \\ Received : October 9, 2020 \\ Revised : February 8, 2021 \\ Accepted : March 1, 2021 \\ Available online : March 31, 2021
}

https://doi.org/10.21098/jimf.v7i0.1312 


\section{INTRODUCTION}

\subsection{Background}

The Covid-19 pandemic began in Wuhan, China, with the first identification of the SARS-CoV-2 virus at the end of 2019, known now as Covid-19 (World Health Organization, 2020). The characteristics of the virus easily transmitted and infect the respiratory system. On January $30^{\text {th }}$, 2020, the World Health Organization (WHO) officially declared SARS-Cov-2 as a public health crisis and finally declared Covid-19 to be a global pandemic. As the time of writing this paper, the virus had infected more than 25 million people in 213 countries and two international conveyances (WHO, 2020). Currently, no clinically tested vaccine is capable of dealing with the virus. Therefore, steps have been taken by many countries to enforce physical distancing or even locking down entire cities in order to mitigate the spread of the virus. In Indonesia, in early March 2020 the government issued a policy of social distancing (maintaining a distance from others, avoiding crowds), physical distancing (keeping a distance between people of at least 1.8 meters), and implementing lockdowns in several areas.

The social distancing and lockdown policies by the government have resulted in a domino effect on other sectors. The global coronavirus crisis (GCC) initially occurred in the health sector. However, the policies developed by each country to prevent the spread of the virus created new problems in the economic, social, political, and environmental sectors. The economic sector has been the most affected dimension, with the policies causing a sudden stop to almost all economic sectors in various countries.

In Europe, there was low economic growth, with an expansion of $0.1 \%$, in the last three months of 2019. The arrival of the Covid-19 pandemic shock escalated this situation. Economic productivity fell by 3.8\% during the first three months of 2020 in the 19 Eurozone countries. In the USA, economic growth in the first two months of 2020 was reasonably stable, but then fell in mid-March as business in the travel industry, restaurants, and retail stores suddenly stopped. The situation has caused more than 35 million people to lose their jobs and become unemployed (Hiscott, Alexandridi, Muscolini, Tassone, Palermo, Soultsioti \& Zevini, 2020). Several global economic indicators show weak demand in various countries, the low expectations of economic actors, and delayed export demand until June 2020. The direct impact of the Covid-19 pandemic on the global economy depends on the duration of the prevention, the rigidity of action taken, and the overall reactions to the spread of the pandemic.

In Indonesia, the impact of Covid-19 has been fairly extensive on the national economy. The country's economic development continues to decline as a result of the impact of the large-scale social restriction (PSBB) policy. National economic growth experienced a $2.97 \%$ slowdown in the first quarter of 2020 compared to the previous growth of $4.97 \%$ year on year. Even in the second quarter of 2020, Indonesia experienced negative economic growth of 5.3\%. In June 2020, it was shown that the economy was starting to recover with the relaxation of PSBB policy, even though it has not returned to pre-pandemic levels. Bank Indonesia data for June 2020 showed that the trade balance for the second quarter of 2020 was a surplus of 2.9 billion US dollars, an increase from the 2.6 billion US dollars of the previous quarter. Other indicators also show improvement, such as in domestic demand, retail sales, and consumer expectations (Bank Indonesia, 2020). 
In the first three months of the Covid-19 pandemic, global wealth decreased by 30\% (Ali, Alam \& Rizvi, 2020). This situation is predicted to continue to worsen, given that the spread of Covid-19 is increasingly out of control, and it is believed that it will have a massive impact on global financial markets. The Covid-19 pandemic has also been shown to lead to high volatility in both the money and capital markets. The dissemination of news through the media is the most determining factor which influences this volatility, having a direct impact on stock price movements in the short term and affecting investors' decisions (Ren, Liao \& Gong, 2020). The research gap is that while study of the volatility of the capital market is extensive, there is relatively little known on how it has been affected by the Covid-19 pandemic.

\subsection{Objective}

In light of the current situation, this research aims to identify the volatility of return on the Islamic capital market in Indonesia with symmetric and asymmetric modeling approaches. It will highlight the asymmetric model of the Islamic capital market in Indonesia during Covid-19 pandemic.

The paper is organised as follows. The introduction includes the background and study objective, while the literature review considers related theory and previous studies. This is followed by the methodology, result and analysis; and finally the conclusion and recommendations.

\section{LITERATURE REVIEW}

\subsection{Asymmetric Volatility of the Stock Market}

Volatility is often defined as the measurement of dispersion around the average return of stock prices. Volatility in one specific stock price is usually associated with the risk of holding that stock. Stock volatility can be caused many factors, both external and internal. It is also well known that each of these factors does not have same level of impact; that is, it is asymmetric. Empirical research has often found that good external factors have a less volatile effect than bad ones.

Talpsepp and Rieger (2010) summarised the causes:

i. Asymmetric volatility could be caused by panel data sources used in the study. Consequently, time-series data prioritisation over panel data is highly recommended, along with the appropriate methodology and analysis.

ii. The leverage effect suggests that asymmetric volatility might be caused by increases in financial leverage.

iii. Asymmetric volatility might also be influenced by news, media and analysts' opinions. To this can be added the possible asymmetric impact caused by current pandemic crisis, with related news spread by analysts through the internet and other media.

iv. Other possible factors for asymmetric volatility are market efficiency, risk premiums, portofolio insurance, individual investors, and the coorporate environment. 


\subsection{Previous Studies}

Rojas-Mora and Chamorro-Futinico (2017) researched countries that are members of the Latin American Integrated Market (MILA). Their study aimed to determine the dynamics of volatility on the MILA stock market index and to determine whether a shock in one country affected the stock markets of other countries, using empirical analysis with three estimated levels of correlation and cointegration of the stock indexes of each country. The research period was from October 2016 to September 2017. Their results show that by using the degree of cointegration calculated by the Johansen cointegration test, there is a long-term relationship between behaviour in index returns, which tends to weaken. Conversely, when calculating cointegration using volatility, there is evidence of a long-term relationship, which tends to become stronger after the establishment of MILA. Their research has practical implications for stock market agents because of the information obtained about the importance of integration among members of MILA.

World financial crises can also cause stock market volatility (Valls Ruiz, 2014). The study of Valls Ruiz aimed to renew interest in understanding the nature of cross-market information transmission using the stock market and exchange rate variables against ten Asian markets and taking into account the impact of the financial crisis. The study used generalized autoregressive asymmetric model analysis (GARCH), with the research period being during the global financial crisis of 2008. The study makes several essential findings; first, there is more evidence of asymmetric response to volatility in the stock market than in the currency market. Second, we found an abundance of bidirectional volatility between the currency and currency markets independently. Third, the transmission of asymmetric volatility can only be observed in a few countries. Finally, we found a mixed effect of the global financial crisis on the volatility transmission pattern. This research is useful for stock traders and practitioners to diversify their portfolios at the international level and invest in assets, both stocks and exchange rates. For policymakers, these findings can be used to calculate the relationship between stock prices and exchange rates before implementing exchange rate policies.

Moreover, the volatility of stock prices can also affect a country's exchange rate, as studied by Bissoondeeal, Hagströmer, Binner, and Mullineux (2014). This study aimed to determine whether volatility in the stock market affected the demand for money in the UK, using M4 analysis to measure money under the relevant literature. The research period was from 1986Q1 to 2006Q4. It was found that there was a relationship between money demand and stock market volatility, mainly due to risk aversion, meaning that the increase was due to prudence rather than transaction motives. This research has the significant implication that money is an indicator of future economic activity. Meanwhile, for policymakers, it is crucial they monitor future inflation due to the increased demand for money.

The interest rates of a country can affect the stock price volatility index (AlMukit, 2013). Al-Mukit aimed to investigate the effect of interest rates on stock market performance using time series data and causality analysis from January 1991 to December 2012 in Bangladesh. The results show that based on Granger causality analysis, there is a unidirectional causality of interest rates on the stock market index. This research has important implications for regulators, and 
policymakers should consider the impact of macroeconomic variables, especially interest rates, before formulating various economic policies. Moreover, the results of the study are essential for formulating market policies in a dynamic capital market development process to ensure the stability of a country's economic growth.

In other research conducted by Kennedy and Nourizad (2016), it was found that exchange rates affect the volatility of stock returns. This study aimed to empirically investigate the effect of USD/euro exchange rate volatility on US stock market volatility using the GARCH model analysis $(1,1)$. The research period was January 1st, 1999 to January 25th, 2010. The results show that the exchange rate had a positive and statistically significant impact on the volatility of stock returns. Moreover, there was another interesting finding, namely that the 9/11 terrorist attacks also increased market volatility. The research has important implications for the financial sector. Federal research could use it to attempt to meet market expectations and also gradually change the money supply. In addition, traders could use the information in this study to take advantage of market volatility.

The relationship between stock price volatility and trading volume was investigated by Koesoemasari, Hadiyanto, Sundari and Harsuti (2017) using dynamic vector autoregression (dynamic VAR) regression analysis. The research investigated 21 shares of companies that were members of the LQ45. The results show that the volatility of stock prices and trading volume has a two-way relationship, and that volume is not an explanatory factor for stock price movements. The implication of the research is that market players such as investment managers, brokers, and investors, can be assistes in making investment decisions by knowing the direction of the volume-price relationship. Their suggestions for further research included testing of the volume-price relationship using dynamic regression methods to explain the relationship between the two variables better.

Asymmetric volatility can also be observed from the pattern of its behaviour. This was studied by Ormos and Timotity (2016), whose purpose was to explain asymmetric volatility based on anchoring behaviour patterns, using historical data analysis of volatility using RV calculations. The data period was from January 2 nd, 1990, to August 7th, 2014. The results show that there was a negative relationship between asymmetry, shocks and volatility. Moreover, it was revealed that implied volatility is not the only predictor of future bias. The implication of the research is that it supportd the theory of asymmetric volatility because the empirical results support the asymmetric effect on volatility and the funding property of anchoring.

Specifically related to the asymmetric volatility model, research by Sari, Achsani, and Sartono (2017) explains that the GARCH asymmetric model could show a better estimate in describing the volatility of stock returns and also that all the observed markets show the existence of an asymmetric effect on stock returns which is statistically significant. The study focused on the volatility of stock returns in four countries in Asia (Indonesia, Singapore, Japan, and Hong Kong) using the asymmetric GARCH model with daily data from 1990 to 2016. The research has important implications for policy authorities to protect market conditions from pessimistic sentiment; moreover, investment players should be careful in observing market fluctuations in determining their investment steps. 
The study also expects that it will help academics in the stock market sector to understand market conditions.

Research by Olbrys and Majewska (2017) also aimed to investigate the asymmetric impact of innovation on volatility in the case of the largest European stock markets in the UK, France, and Germany, using an EGARCH-based approach. The research data was from January 2003 to December 2016. The results show that the negative impact of innovation has a higher effect on volatility than a positive impact. The critical implication of this negative impact of innovation is under investors' intuition. Investors should therefore be more careful because the financial economy of Europe is "connected every day," not only during financial crises.

In the case of Malaysia, Ghazali and Lean (2015) analysed an asymmetrical model of the gold price in response to negative and positive news during the extreme downturn in the stock market using GARCH-based volatility modelling analysis. The research period was from July 2001 to May 2014. It was found that the volatility of the gold price showed a symmetric reaction to positive and negative shocks in the capital market. The research therefore encouraged retail investors to invest in gold through regular small-scale purchases, thereby protecting themselves from the volatility of gold prices.

Research on asymmetric volatility in African countries was conducted by Uyaebo, Atoi and Usman (2015). Their study aimed to compare the asymmetric volatility of stock markets in African countries (Nigeria, Kenya, and South Africa) with the situation in the United States, Germany, and China, using GARCH model analysis. The research data period was from February 14th, 2000, to February 14th, 2013. The results show that the stock returns of Nigeria and Kenya reacted to market shocks faster than those in other countries. Other results show no leverage effect in Nigeria and Kenya. The research implies that regulators must be able to read the situation of the stock market in Nigeria and Kenya because both countries have less developed markets. Therefore, more developed market infrastructure is urgently needed in the effort to fight rapid reactions to market fluctuations.

Vulandari (2015) examined the asymmetric volatility model in Islamic and conventional stock markets in Indonesia. The purpose of this study was to analyse whether the IHSG and ISSI had asymmetric characteristics in their returns and to find if there was a cointegration relationship between IHSG and ISSI. The research period was from June 22nd, 2011, to August 15th, 2014. Several findings were made, including that there was an asymmetrical relationship and a cointegration relationship between IHSG and ISSI returns, but no causal relationship between IHSG and ISSI. Second, ISSI returns were influenced by JCI returns. Third, the EGARCH-ECM model was a better model to use for data on ISSI returns. The implications of this research are essential for investors to increase their knowledge about the Islamic and conventional stock markets in Indonesia.

Further research on the asymmetric model of volatility was conducted by Albu, Lupu and Călin (2015). Their study aimed to measure the effect of asymmetric volatility on the dynamics of the East European stock market and to detect its relationship with the development of the macroeconomic environment, using GARCH model analysis with coefficients for the asymmetric effect. The research period was from October 20th, 2000 to September 18th, 2014, employing data 
from the stock markets of Poland, the Czech Republic, Hungary, and Romania. The results show that there was a difference in the asymmetric phenomenon in Romania and the cases that occurred in Poland, the Czech Republic, and Hungary. The implication of the research results is that they provide knowledge for people in the four countries to understand phenomena in their respective countries better, so that the impact of asymmetric volatility can be predicted and thus be considered by investors.

In addition, Ho, Tsui and Zhang (2013) analysed the condition of asymmetric volatility using business cycle indicators in four OECD countries. The research period covered January 1961 to December 1997, with data taken from the official OECD website using GARCH analysis. The results show that asymmetric volatility was detected significantly in the UK and the US. The research has the important implication that policymakers need to develop more vital international policy coordination among countries experiencing adverse growth shocks.

Considering the different impact between good news and bad news on the volatility of data research, Babu, Kumar and Naganjaneyulu (2020) researched the effect of good news and bad news on fluctuations in the Nifty Bank index, using the EGARCH analysis model $(1,1)$. The research data period was from January 2009 to December 2018. The results show that the negative coefficient was significant. Another finding was the leverage effect on the Nifty Bank index, with bad news affecting the fluctuations more than good news.

The development of the GARCH model is currently fairly rapid, with many models introduced to cover the shortcomings of the previous model in predicting and interpreting the volatility of returns. The multivariate GARCH model was reviewed by Bauwens, Laurent and Rombouts (2006), who iferences the method and identified a possible model for the research in the future. Other research on multivariate GARCH can be found in many studies; see for example, Ali (2013), Miralles-Marcelo, Miralles-Quirós \& Miralles-Quirós (2013) and Saida, Sudarno \& Hoyyi (2016).

After reviewing these previous studies, the causes of asymmetric volatility are varied, as claimed by Talpsepp and Rieger (2010). Most of the studies used time series data analysis because the nature of volatility relates to the dispersion of time series around the average. While macroeconomic aspects (interest rates, exchange rates, GDP, inflation, etc), market conditions, risk, and other possible factor are also effective in explaining asymmetric volatility in the stock market, what remains a puzzle is that the shock in the stock market could unsurely be less or more volatile as the impact of an event, especially the Covid-19 pandemic. Therefore, this study attempts to analyse the asymmetric behaviour of Islamic capital market volatility during the pandemic.

\section{METHODOLOGY}

\subsection{Data}

The time-series data used in the study were the prices of the Indonesian Sharia Stock Index (ISSI) at the close of daily stock trading during the period January 2nd, 2020 , to July 17th, 2020. This first 200-day period was specially chosen in order to determine the behaviour of Islamic stock prices in Indonesia during the Covid-19 
pandemic. The selection of the ISSI as a proxy for the Islamic stock market rather than the Jakarta Islamic Index (JII) or JII70 was because the ISSI includes all sharia shares that have passed the verification of the National Sharia Council of the Indonesian Ulama (DSN MUI). The JII and JII70 only included 30 and 70 of the most liquid Islamic stocks respectively.

As a preliminary analysis, the first 200 days after the first confirmed case of the Covid-19 pandemic is scientifically sufficient. Khorram and Sheshmani (2015) used 1 - 200 days (Simple Moving Average 200 / SMA-200) of stock prices to find the most appropriate prediction. They found a good prediction of the stock price even only for no more than 200 days, so we believe this justifies the level of daily data for our study. In addition, Chang, Ilomäki, Laurila \& McAleer (2018) and Williams (2006) used the same period in their research to predict the volatility of the return.

\subsection{Model Development}

The return on Islamic stock prices was calculated using the following equation:

$$
R I S S I=\left(I S S I_{t}-I S S I_{t-1}\right) / I S S I_{t-1}
$$

where $I S S I_{t}$ is the Indonesia Sharia Stock Index at t, and $I S S I_{t-1}$ is the Indonesia Sharia Stock Index at the previous of $t$.

The study uses symmetric (standard GARCH) and asymmetric (Threshold GARCH) analysis to observe the volatility behaviour of Islamic stock prices in Indonesia during the Covid-19 pandemic. We also used the ADF unit root test, the unit root test with breakpoint selection, and forecasting volatility. These tests aimed to observe the degree of data stationarity, to determine when a break date occurred at each degree of stationarity, and to predict the volatility behaviour of Islamic stock prices during the Covid-19 pandemic.

Autoregressive conditional heteroskedasticity (ARCH) is an impressive analytical model to establish the volatility behaviour of data and to make forecasts based on their conditional variance. The variant of the dependent variable is a function of the past value of the dependent variable itself, the independent variable, or the exogenous variable. The ARCH model was first introduced by Engle (1982), while the generalized ARCH (GARCH) model was popularised by Bollerslev (1986).

The standard GARH model used in this study is as follows:

$$
\begin{aligned}
& Y=X_{t}^{\prime} \theta+\epsilon_{t} \\
& \alpha_{t}^{2}=\omega+\alpha \epsilon_{t-1}^{2}+\beta_{t-1}^{2}
\end{aligned}
$$

Equation (2) is a mean equation as a function of an exogenous variable with an interference variable. Equation (3) is a conditional variance equation as a function of constant $(\omega)$, the volatility of the previous period $\left(\alpha \epsilon_{t-1}^{2}\right)$, and predictive variants in the final period $\left(\beta_{t-1}^{2}\right)$, in which $\alpha \epsilon_{t-1}^{2}$ and $\beta_{t-1}^{2}$ are usually interpreted as ARCH and GARCH effects. 


$$
\alpha_{t}^{2}=\omega+\Sigma_{j=1}^{q} \beta_{j} \sigma_{t-j}^{2}+\Sigma_{i=1}^{p} \alpha_{i} \varepsilon_{t-i}^{2}
$$

In particular, this study used the GARCH model $(1,1)$ following research conducted by Nguyen and Nguyen (2019), who examined the volatility of share prices in Vietnam. Equation (4) explains that the variant of $\alpha_{t}^{2}$ depends on the past value of shock, represented by the squared disturbance class and past values of the variants $\alpha_{t}^{2}$ its self represented by $\alpha_{t-1}^{2}$.

\subsection{Method}

One of the weaknesses of the GARCH model is that the analysis is symmetrical, meaning that it uses the absolute value of the shock factor that occurs, regardless of whether positive or negative shocks have a smaller or larger effect on volatility. The importance of employing symmetric GARCH and asymmetric TGARCH in this study is that there exists a difference between negative and positive shocks in relation to the volatility effect. Empirical research has often found that a positive shock caused by a good event has a less volatile effect than a negative shock caused by an adverse event. Therefore, this study also uses the Threshold GARCH (TGARCH) model to identify whether the negative shock from the Covid-19 pandemic has had a greater influence on the volatility of Islamic stock prices in Indonesia than other positive shock events.

The standard procedures of GARCH analysis consist of a stationary test, $\mathrm{ARCH}$ effect test, model analysis and forecasting variance analysis. In order to meet the criteria of the GARCH analysis, we followed all the standard procedure requirements.

The TGARCH model was introduced by Glosten, Jagannathan and Runkle (1993) and Zakoian (1994) in order to separate the impact from negative and positive shocks asymmetrically. The possible differences are described in the model; the equation for the TGARCH model in this study is as follows:

$$
\alpha_{t}^{2}=\omega+\Sigma_{j=1}^{q} \beta_{j} \sigma_{t-j}^{2}+\sum_{i=1}^{p} \alpha_{i} \varepsilon_{t-i}^{2}+\Sigma_{k=1}^{r} \gamma_{k} \varepsilon_{t-k}^{2} I_{t-k}^{-}
$$

where $I_{t}^{-}=1$ if $\varepsilon_{t}<0$ and 0 if adversely. Equation (5) shows that good news $\varepsilon_{t-1}>0$ and bad news $\varepsilon_{t-1}>0$ do not have the same level of impact on conditional variance. Good news has an $\alpha_{i}$ impact, whereas bad news has an $\alpha_{i}+\gamma_{i}$ impact on volatility.

In order to measure the asymmetric model of volatility, researchers often use EGARCH, TGARCH, NGARCH, APARCH, IGARCH, GJR-GARCH, and AVGARCH. The models are not radically different from one another, although Ali (2013) found that TGARCH was far better than the other models in capturing the response of volatility.

\section{RESULTS AND ANALYSIS}

\subsection{General Condition of the Indonesia Sharia Stock Index (ISSI)}

The Covid-19 pandemic was first discovered in Wuhan, China, at the end of 2019. At first, it was called SARS-CoV-2, which later changed to 2019-nCoV (2019 novel coronavirus). Furthermore, the World Health Organization (WHO) issued 
an official statement calling the outbreak (coronavirus disease) Covid-19. During the pandemic period, the ISSI continued to fall, IDR 187,580 at the beginning of 2020, to IDR 115,946 on March 24th, 2020. After that, it recorded an increasing but relatively modest trend, so that at the end of this study, July 17th, 2020, it was only at the level of IDR 148,841. In general, the ISSI fell by 38.30 percent until the end of March 2020, and then increased by 28.37 percent. However, it has still not been able to reach the same level as before the Covid-19 pandemic occurred. Figure 1 illustrates this movement.

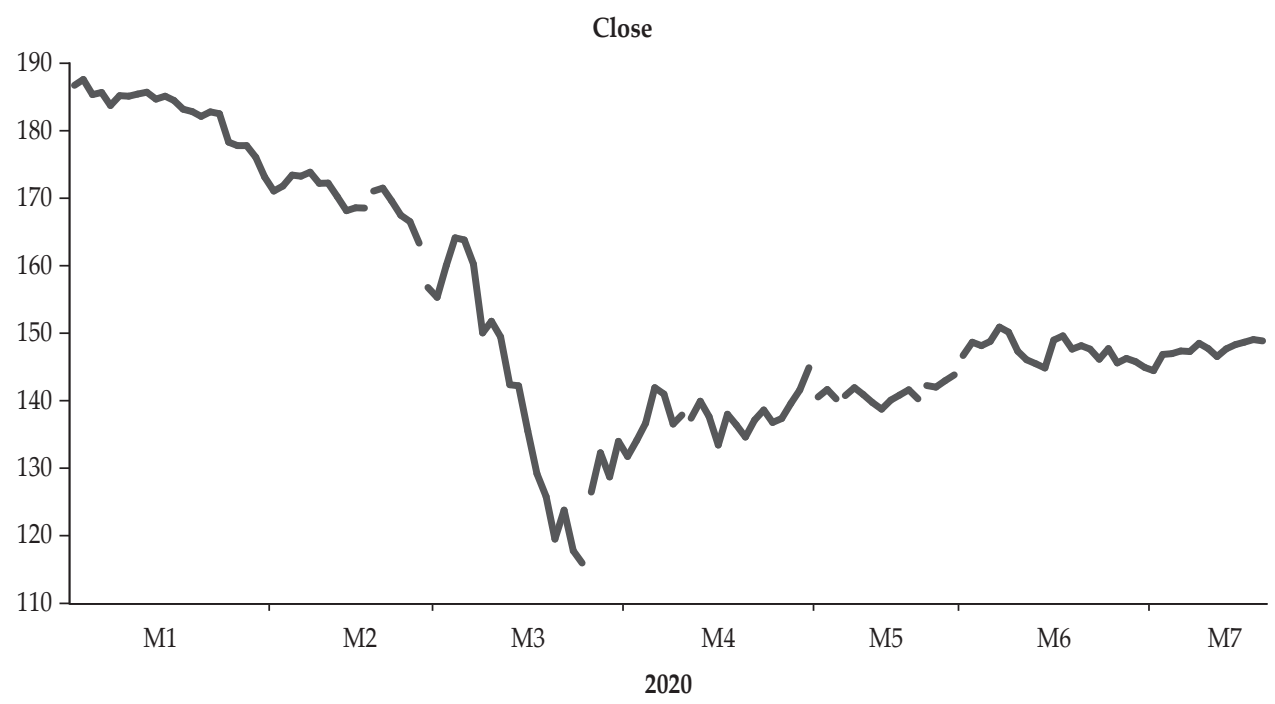

Figure 1.

ISSI Movement During the Covid-19 Pandemic (IDR)

It was further examined whether the ISSI variable had a break date point during the study period. We employed the ADF data stationarity test and the Dickey-Fuller stationarity test with the breakpoint selection introduced by Perron (1997) to identify the break.

Table 1.

ADF Stationarity Test

\begin{tabular}{lcccc}
\hline \multirow{2}{*}{ Unit root test } & \multicolumn{2}{c}{ ADF } & DF with breakpoint selection \\
\cline { 3 - 5 } & & t-statistic & Prob & Break date \\
\hline \multirow{2}{*}{ ISSI } & Level & -1.901875 & 0.3306 & February $20^{\text {th }}, 2020$ \\
& $1^{\text {st }}$ Difference & -10.30394 & $0.0000^{*}$ & March 26 $6^{\text {th }}, 2020^{*}$ \\
\hline
\end{tabular}

* indicates $5 \%$ significance level

The probability values show that the ISSI variable was not stationary at the level or $1^{\text {st }}$ Difference. 
It is widely known that time-series data variables often face stationarity problems, so this study included a stationarity test. Figure 2 shows the results of the DF stationarity test with break point selection.
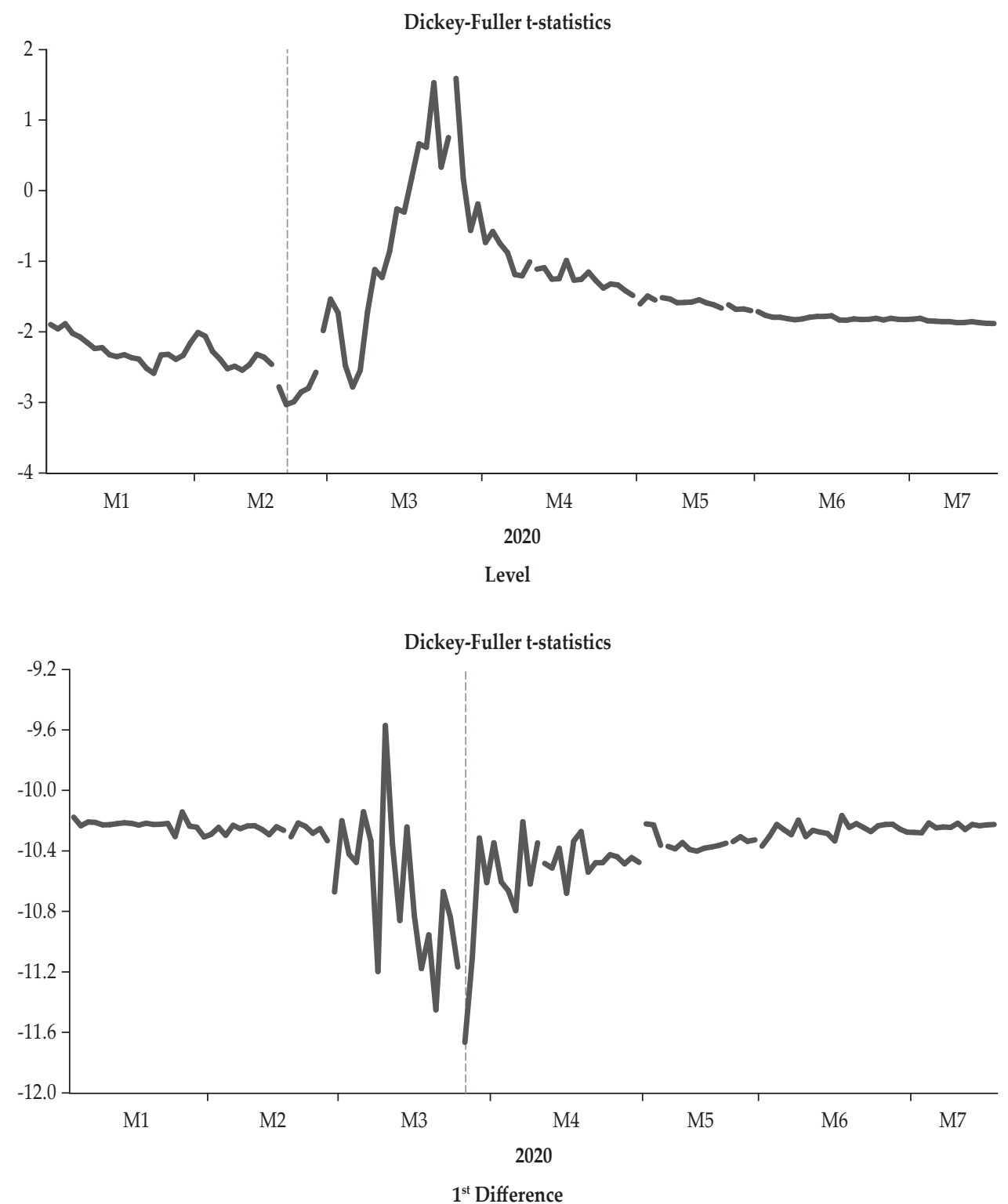

Figure 2.

DF Stationarity test with Breakpoint Selection 
From the results of the stationarity test with breakpoint selection, the Indonesian Islamic stock index experienced a sharp downward fluctuation until March 26th, 2020, before gradually rising.

\subsection{Asymmetric Volatility of Return on ISSI during the Covid-19 Pandemic}

The return on the ISSI variable has an average value of -0.15 , with a minimum of -6.34 and maximum of 9.08 , while the kurtosis value of 6.91 and the Jarque-Bera probability are statistically significant at the 1 percent level. These results indicate that the return was not normally distributed. Figure 4 shows that the Islamic stock price index fluctuated during the Covid-19 pandemic, consecutively moving up and down around the average.

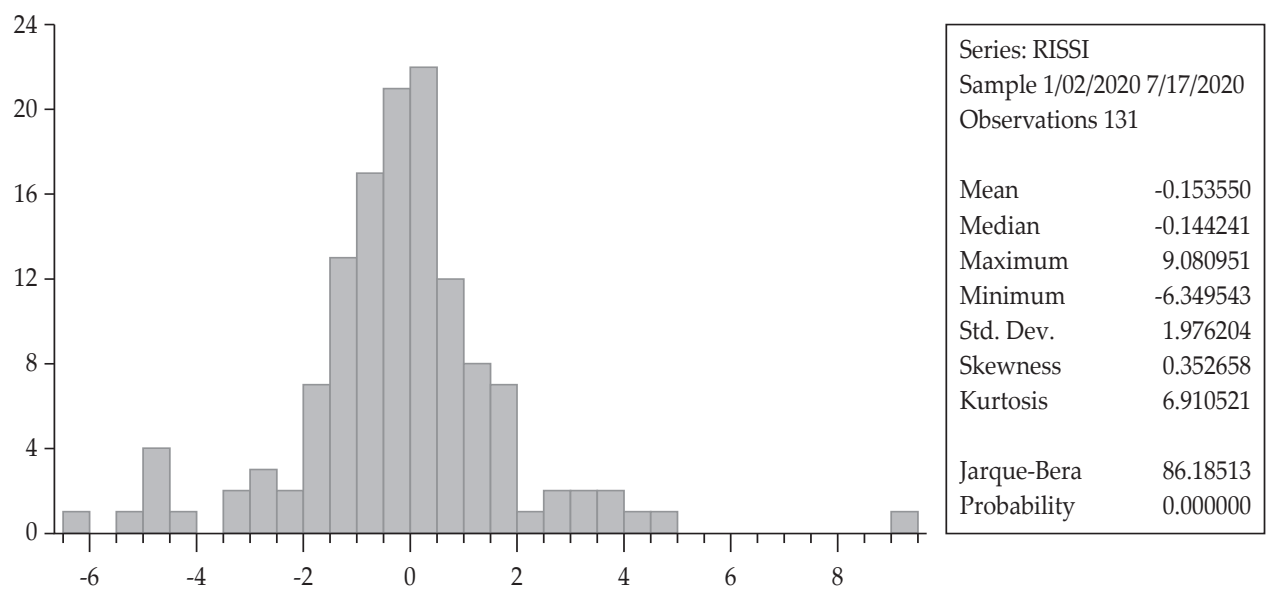

Figure 3.

Descriptive Statistics of ISSI Return

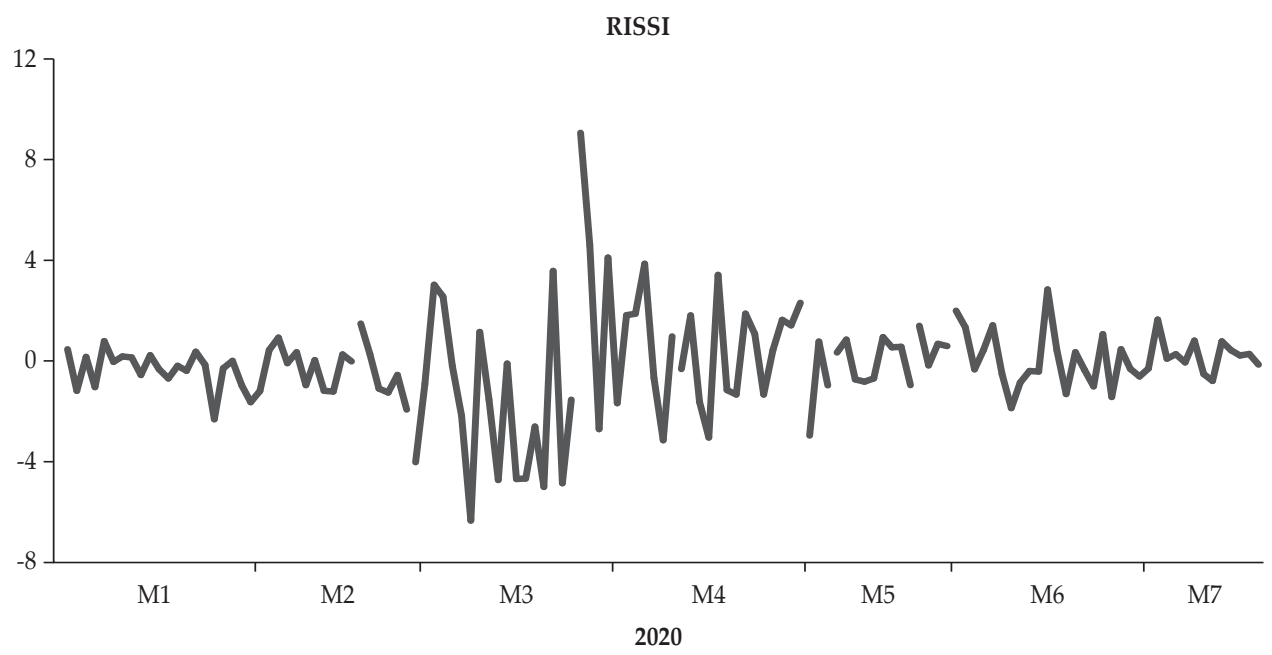

Figure 4.

ISSI Volatility of Return 
Furthermore, the results of the ARCH specification diagnostic using ARCHLM reveal that the probability value of $\mathrm{F}$ and chi-square are statistically significant at the $5 \%$ level. The ARCH analysis, as well as thst of GARCH and TGARCH, are appropriate models to be employed in this study (See Table 2).

Table 2.

ARCH Effect Test

\begin{tabular}{lccc}
\hline \multicolumn{4}{c}{ Heteroskedasticity Test: ARCH } \\
\hline F-statistic & 4.510365 & Prob. F(1,127) & 0.0356 \\
Obs*R-squared & 4.424268 & Prob. Chi-Square(1) & $0.0354^{*}$ \\
\hline
\end{tabular}

* indicates 5\% significance level

We then obtained the best models for the GARCH selection analysis, which were GARCH $(1,1)$ and TGARCH $(1,1)$. The results using the GARCH $(1,1)$ model in the mean equation showed a negative coefficient, which was not statistically significant. The present value of return on ISSI does not have a significant effect on its future value. During the Covid-19 pandemic, the average value of return on Islamic stocks was -0.062797 , which means that Islamic shareholders were still experiencing losses. However, the present price of Islamic stocks is still considerably calculated for the forecast of the variance in the following period.

Meanwhile, the analysis of the GARCH model $(1,1)$ in the conditional variance equation shows the existence of volatility in Islamic stock prices during the Covid-19 pandemic. This can be calculated at a constant value of 0.110241 plus the previous share price of 0.741736 and the value of other components depending on the previous share price of 0.230149 . All the coefficients on the conditional variance specification meet the stability assumption, where $\alpha+\beta<1$, as shown in Table 3 .

Table 3.

Results of GARCH $(1,1)$ and TGARCH $(1,1)$ Regression

\begin{tabular}{|c|c|c|}
\hline Coefficient & GARCH $(1,1)$ & TGARCH $(1,1)$ \\
\hline \multicolumn{3}{|l|}{ Mean Equation } \\
\hline $\mathrm{C}$ & -0.062797 & $-0.158615^{* *}$ \\
\hline RISSI(-1) & -0.000452 & 0.019153 \\
\hline \multicolumn{3}{|l|}{ Variance Equation } \\
\hline $\mathrm{C}$ & 0.110241 & -0.002143 \\
\hline $\operatorname{RESID}(-1)^{\wedge} 2$ & $0.230149^{* *}$ & $-0.160834^{* * *}$ \\
\hline $\operatorname{RESID}(-1)^{\wedge} 2^{*}(\operatorname{RESID}(-1)<0)$ & - & $0.274254^{* * *}$ \\
\hline GARCH(-1) & $0.741736^{* * *}$ & $1.032543^{* * *}$ \\
\hline Log Likelihood & -235.0364 & -226.4179 \\
\hline $\mathrm{AIC}$ & 3.692868 & 3.575661 \\
\hline SIC & 3.803157 & 3.629438 \\
\hline
\end{tabular}

****, and ${ }^{*}$ indicate levels of significance of $1 \%, 5 \%$, and $10 \%$ 
The volatility of Indonesian Islamic stock prices during the Covid-19 pandemic was also relatively high, with the sum of the ARCH and GARCH parameters reaching a value of 0.97 . It would be very beneficial for future research to compare the difference between Islamic and conventional capital market volatility during the pandemic.

Furthermore, in order to determine the asymmetric model of the return on ISSI volatility during the Covid-19 pandemic, the TGARCH $(1,1)$ model was used The results show that the coefficient of asymmetric parameters is positive and statistically significant. Good news and bad news does not have the same level of impact on the volatility of ISSI return. Furthermore, coefficients $\alpha_{i}$ and $\gamma_{i}$ in the variance equation indicate that good news has a stronger volatility impact than bad news. Good news has an $\alpha_{i}$ impact, while bad news has a $\alpha_{i}+\gamma_{i}$ impact on volatility. Figure 5 shows the volatility of Islamic stock prices during the Covid-19 pandemic using variance forecasting analysis.
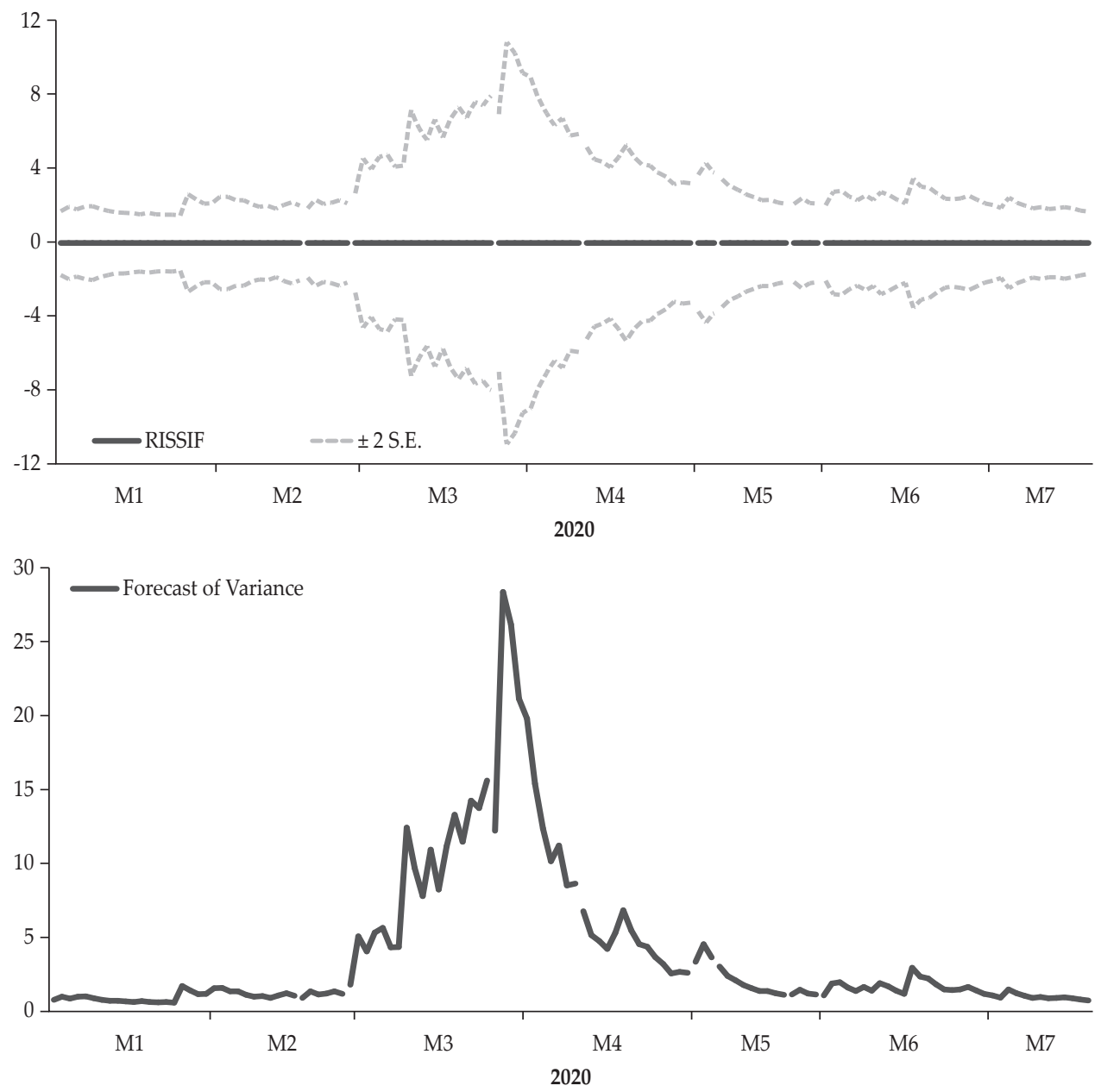

Figure 5.

Variance Forecasting Analysis 
This finding is in line with the studies of Ormos and Timotity (2016), Sari et al., (2017), and Olbrys and Majewska (2017), in which the asymmetric model of stock volatility exists in their results.

\subsection{Analysis}

We found that the Islamic stock price index fluctuated during the Covid-19 pandemic, consecutively moving up and down around the average. A further finding was that the price of the Islamic capital market experienced diminishing returns during the pandemic. Volatility was relatively high at the beginning but subsequently decreased slowly. The diminishing return effect could be because the public's fear of Covid-19 only lasted in the first month, after which it slowly disappeared. Another reason why the effects of the pandemic were only felt at the beginning of the outbreak is because of the success of government policies in providing economic stimulus to almost all business sectors. This might be good news for investors. From the coefficient of asymmetric parameters, which is positive and statistically significant, we found that good news and bad news does not have the same level of impact on volatility. Our study confirms that good news concerning government policies had a greater impact on volatility than bad news about the spread of the disease. However, this finding is not in line with the study of Babu et al., (2020) which might be due to specific event related to pandemic and the absence of governance response in their study.

The government policies include, but are not limited to, increasing spending in the health sector, providing incentives for health workers, eliminating several types of tax for micro, small, medium, and large entrepreneurs, restructuring credit, making cash transfers to those directly affected, and cancelling or discounting electricity bills for the lower and middle classes. These policies appear to be successful in stimulating economic activity. However, the government should also continue its control of the spread of the virus, because there will always be a tradeoff between economic activity and the spread.

\section{CONCLUSION AND RECOMMENDATIONS}

\subsection{Conclusion}

Symmetric analysis with the GARCH $(1,1)$ model and asymmetrical analysis with the TGARCH $(1,1)$ model was made in order to identify the volatility of return in the Islamic capital market in Indonesia during the Covid-19 pandemic. Daily time series data from January 2nd, 2020 to July 17th, 2020 were used, derived from the daily closing price of the Indonesia Sharia Stock Index (ISSI). The results show that the return on ISSI has experienced diminishing volatility during the Covid-19 pandemic. At the same time, the price of ISSI fell sharply, followed by a gradual rise. Based on the unit root test with Dickey-Fuller breakpoint analysis, the break date was March 26th, 2020.

The GARCH model $(1,1)$ in the conditional variance equation indicated that there was volatility in Islamic stock prices during the Covid-19 pandemic. However, one of the weaknesses of the GARCH model is that the analysis is symmetrical. Therefore, the Threshold GARCH (TGARCH) model was also employed to 
identify whether the negative shock from the Covid-19 pandemic has had a greater influence on the volatility of Islamic stock prices in Indonesia than other positive shock events.

The results of the TGARCH $(1,1)$ model show that the coefficient of asymmetric parameters is positive and statistically significant. Good news and bad news do not have the same level of impact on the volatility of ISSI return. Furthermore, coefficients $\alpha_{i}$ and $\gamma_{i}$ in the variance equation indicate that good news has a greater volatility impact than bad news. Good news has an $\alpha_{i}$ impact, while bad news has an $\alpha_{i}+\gamma_{i}$ impact.

\subsection{Recommendations}

It is considered that the Covid-19 pandemic is an example of bad news, having a low impact on the volatility of return on the ISSI. It is recommended that traders should not to worry about the bad news effect of the pandemic. Its impact on the volatility of the Islamic capital market does exist, but fear of loose on holding such stock is not really necessary. The results show that the bad news effect of Covid-19 through the media is less volatile than that of good news. An example of good news for investors is that the government's concern for helping impacted people seems to be well organised.

For that reason, the government should continue its efforts to stop the spread of the virus, alongside its economic recovery policies. Finally, a suggestion for future study is to make a comparison between Islamic and conventional capital market behaviour during the Covid-19 pandemic with a wider range of data.

\section{REFERENCES}

Al-Mukit, D. M. (2013). The effects of interest rates volatility on stock returns: Evidence from Bangladesh. International Journal of Management and Business Research, 3(3), 269-279.

Albu, L. L., Lupu, R., \& Călin, A. C. (2015). Stock market asymmetric volatility and macroeconomic dynamics in Central and Eastern Europe. Procedia Economics and Finance, 22(2015), 560-567. https://doi.org/10.1016/S2212-5671(15)00259-2.

Ali, G. (2013). Egarch, gjr-garch, tgarch, avgarch, ngarch, igarch and aparch models for Pathogens at marine recreational sites. Journal of Statistical and Econometric Methods, 2(3), 57-73.

Ali, M., Alam, N., \& Rizvi, S. A. R. (2020). Coronavirus (COVID-19) - An epidemic or pandemic for financial markets. Journal of Behavioral and Experimental Finance, 27(September 2020), 100341. https://doi.org/10.1016/j.jbef.2020.100341.

Babu, P. R., Kumar, S. R., \& Naganjaneyulu, A. V. (2020). Modelling asymmetric volatility: Evidence from India. Journal of Critical Reviews, 7(9), 845-850. https:// doi.org/10.31838/jcr.07.09.158.

Bauwens, L., Laurent, S., \& Rombouts, J. V. K. (2006). Multivariate GARCH models: A survey. Journal of Applied Econometrics, 21(1), 79-109. https://doi.org/10.1002/ jae.842.

Bissoondeeal, R. K., Hagströmer, B., Binner, J. M., \& Mullineux, A. (2014). Stock market volatility, risk attitude and the demand for money in the UK. 
Working Paper No.21342. Eprints Bournemouth University, 1-24. http://eprints. bournemouth.ac.uk/21342/3/Rakesh\%2520paper-1.pdf.

Bollerslev, T. (1986). Generalized autoregressive conditional heteroskedasticity. Journal of Econometrics, 31(3), 307-327. https://doi.org/10.1016/03044076(86)90063-1

Chang, C. L., Ilomäki, J., Laurila, H., \& McAleer, M. (2018). Long run returns predictability and volatility with moving averages. Risks, 6(4), 105. https://doi. org/10.3390/risks6040105.

Engle, R. F. (1982). Autoregressive conditional heteroscedasticity with estimates of the variance of United Kingdom inflation. Econometrica, 50(4), 987-1007. https://doi.org/10.2307/1912773.

Ghazali M. F., \& Lean H. H. (2015) Asymmetric volatility of local gold prices in Malaysia. In: Huynh VN., Kreinovich V., Sriboonchitta S., Suriya K. (eds) Econometrics of Risk. Studies in Computational Intelligence (Vol. 583, pp. pp. 203-218. Cham: Springer. https://doi.org/10.1007/978-3-319-13449-9_14.

Glosten, L. R., Jagannathan, R., \& Runkle, D. E. (1993). On the relation between the expected value and the volatility of the nominal excess return on stocks. The Journal of Finance, 48(5), 1779-1801. https://doi.org/10.1111/j.1540-6261.1993. tb05128.x.

Hiscott, J., Alexandridi, M., Muscolini, M., Tassone, E., Palermo, E., Soultsioti, M., \& Zevini, A. (2020). The global impact of the coronavirus pandemic. Cytokine \& Growth Factor Reviews, 53(June 2020), 1-9. https://doi.org/10.1016/j. cytogfr.2020.05.010.

Ho, K.-Y., Tsui, A. K., \& Zhang, Z. (2013). Conditional volatility asymmetry of business cycles: Evidence from four OECD countries. Journal of Economic Development, 38(3), 33-55. https://doi.org/10.35866/caujed.2013.38.3.002.

Bank Indonesia. (2020). Monetary policy review June 2020. Retrevied from https:// www.bi.go.id/en/publikasi/laporan/Documents/Monetary_Policy_Review_ June_2020.pdf.

Kennedy, K., \& Nourizad, F. (2016). Exchange rate volatility and its effect on stock market volatility. International Journal of Human Capital in Urban Management, 1(1), 37-46. http://www.ijhcum.net/article_19121_ a4c266151330aafd7795dda447eab298.pdf.

Khorram, M., \& Sheshmani, M. (2015). What period of time is better to use for moving average to predict stock price in Tehran stock exchange? Indian Journal of Science and Technology, 8(27), 1-8. https://doi.org/10.17485/ijst/2015/ v8i27/82640.

Koesoemasari, D. S. P., Hadiyato, K., Sundari, S., \& Harsuti. (2017). Hubungan antara volatilitas harga saham dan volume perdagangan saham di Bursa Efek Indonesia. Sustainable Competitive Advantage-7 (SCA-7). FEB UNSOED. http:// jp.feb.unsoed.ac.id/index.php/sca-1/article/view/1020.

Miralles-Marcelo, J. L., Miralles-Quirós, J. L., \& Miralles-Quirós, M. del M. (2013). Multivariate GARCH models and risk minimizing portfolios: The importance of medium and small firms. The Spanish Review of Financial Economics, 11(1), 29-38. https://doi.org/10.1016/j.srfe.2013.03.001.

Nguyen, C. T., \& Nguyen, M. H. (2019). Modeling stock price volatility: Empirical evidence from the Ho Chi Minh City stock exchange in Vietnam. Journal of 
Asian Finance, Economics and Business, 6(3), 19-26. https://doi.org/10.13106/ jafeb.2019.vol6.no3.19.

Olbrys, J., \& Majewska, E. (2017). Asymmetry effects in volatility on the major European stock markets: The EGARCH based approach. Quantitative Finance and Economics, 1(4), 411-427. https://doi.org/10.3934/QFE.2017.4.411.

Ormos, M., \& Timotity, D. (2016). Unravelling the asymmetric volatility puzzle: A novel explanation of volatility through anchoring. Economic Systems, 40(3), 345-354. https://doi.org/10.1016/j.ecosys.2015.09.008.

Perron, P. (1997). Further evidence on breaking trend functions in macroeconomic variables. Journal of Econometrics, 80(2), 355-385. https://www.sciencedirect. com/science/article/abs/pii/S0304407697000493.

Ren, Y., Liao, F., \& Gong, Y. (2020). Impact of news on the trend of stock price change: An analysis based on the deep bidirectiona LSTM model. Procedia Computer Science, 174(2020), 128-140. https://doi.org/10.1016/j.procs.2020.06.068.

Rojas-Mora, J., \& Chamorro-Futinico, J. C. (2017). Dynamics and volatility at stock market indexes of pacific alliance countries. Panorama Economico, 24(October 2016 - September 2017), 71-84.

Saida, M. D. N., Sudarno, \& Hoyyi, A. (2016). Pemodelan return indeks harga saham gabungan menggunakan threshold generalized autoregressive conditional heteroscedasticity (TGARCH). Jurnal Gaussian, 5(3), 465-474.

Sari, L. K., Achsani, N. A., \& Sartono, B. (2017). Pemodelan volatilitas return saham: Studi kasus pasar saham Asia. Jurnal Ekonomi dan Pembangunan Indonesia, 18(1), 35-52. https://doi.org/10.21002/jepi.v18i1.717.

Talpsepp, T., \& Rieger, M. O. (2010). Explaining asymmetric volatility around the world. Journal of Empirical Finance, 17(5), 938-956. https://doi.org/10.1016/j. jempfin.2010.08.005.

Uyaebo, S. O., Atoi, V. N., \& Usman, F. (2015). Nigeria stock market volatility in comparison with some countries: Application of asymmetric GARCH models. CBN Journal of Applied Statistics, 6(2), 133-160.

Valls Ruiz, N. (2014). Volatility in financial markets: The impact of the global financial crisis. Ph.D Thesis. Universitat de Barcelona. http://diposit.ub.edu/dspace/ bitstream/2445/65063/1/NVR_PhD_THESIS.pdf.

Vulandari, R. T. (2015). Perbandingan model asimetris volatilitas return indeks saham dengan EGARCH dan EGARCH-ECM pada pasar saham syariah dan konvensional [Institut Teknologi Sepuluh Nopember.]. http://repository.its.ac.id/51875/.

WHO. (2020). Coronavirus disease (COVID-19) pandemic. Retrevied from https://www.who.int/emergencies/diseases/novel-coronavirus2019? gclid=EAIaIQobChMIOIaU-7qB7wIVBZVLBR36LAbTEAAYASAAEgKv 1_D_BwE

Williams, O. D. (2006). Empirical optimization of bollinger bands for profitability (August 8, 2006). Simon Fraser University Library. Available at SRRN : https:// doi.org/10.2139/ssrn.2321140.

World Health Organization (2020). Covid-19 Situation Report. World Health Organization, 31(2), 61-66.

Zakoian, J.-M. (1994). Threshold heteroskedastic models. Journal of Economic Dynamics and Control, 18(5), 931-955. https://doi.org/10.1016/01651889(94)90039-6. 